\title{
The Contribution of SPECT/CT in the Diagnosis of Stress Fracture of the Proximal Tibia
}

\author{
Proksimal Tibia Stres Kırığında SPECT/BT'nin KatkıSı
}

(1) Berna Okudan, (1) Nazım Coşkun, (1) Pelin Arıcan

University of Health Sciences, Ankara Numune Training and Research Hospital, Clinic of Nuclear Medicine, Ankara, Turkey

\begin{abstract}
Stress fractures are injuries most commonly seen in the lower limbs and are usually caused by repetitive stress. While the distal and middle third of the tibia is the most frequent site for stress fractures (almost 50\%), stress fractures of the proximal tibia is relatively rare and could be confused with other types of tibial fractures, thus altering management plans for the clinician. Early diagnosis of stress fractures is also important to avoid complications. Imaging plays an important role in the diagnosis of stress fractures, especially bone scan. Combined with single-photon emission computed tomography/computed tomography (SPECT/CT) it is an important imaging technique for stress fractures in both upper and lower extremities, and is widely preferred over other imaging techniques. In this case, we present the case of a 39-year-old male patient diagnosed with stress fracture of the proximal tibia and demonstrate the contribution of CT scan fused with SPECT imaging in the early diagnosis of stress fracture prior to other imaging modalities.
\end{abstract}

Keywords: Stress fracture, proximal tibia, bone scintigraphy, single-photon emission computed tomography/computed tomography

\section{Öz}

Stres kırıkları çoğunlukla alt ekstremitede görülen ve genellikle tekrarlayan strese bağlı gelişen yaralanmalardır. Tibia orta kesimi ve distali stres kırıklarının en sık görüldüğü bölgeler iken (yaklaşık \%50), proksimal tibianın stres kırıkları nispeten nadirdir, diğer kırık türleriyle karıştıılabilir ve bu durum klinisyenin tedavi planını etkileyebilir. Stres kıııklarının erken tanısı komplikasyonları önlemek açısından önemlidir. Görüntüleme yöntemleri, stres kırıklarının teşhisinde önemli bir rol oynamaktadır. Özellikle tekfoton emisyon bilgisayarlı tomografi/bilgisayarlı tomografi (SPECT/BT) ile birleştirilen kemik sintigrafisi hem üst hem de alt ekstremite stres kııkları için önemli bir görüntüleme tekniğidir ve diğer görüntüleme tekniklerine göre çok daha fazla tercih edilmektedir. Bu yazıda proksimal tibiada stres kırığı tanısı alan 39 yaşındaki bir erkek hastanın hikayesini sunuyor ve stres kırı̆ıının erken tanısında SPECT/BT taramasının katkısını gösteriyoruz.

Anahtar kelimeler: Stres kırı̆ı̆ı, proksimal tibia, kemik sintigrafisi, tek-foton emisyonlu bilgisayarlı tomografi/bilgisayarlı tomografi

Address for Correspondence: Nazım Coşkun MD, University of Health Sciences, Ankara Numune Training and Research Hospital, Clinic of Nuclear Medicine, Ankara, Turkey

Phone: +90 5343288474 E-mail: nazimcoskun@gmail.com ORCID ID: orcid.org/0000-0002-1458-9392

Received: 25.06.2016 Accepted: 15.10.2017

${ }^{\circ}$ Copyright 2018 by Turkish Society of Nuclear Medicine

Molecular Imaging and Radionuclide Therapy published by Galenos Yayınevi. 


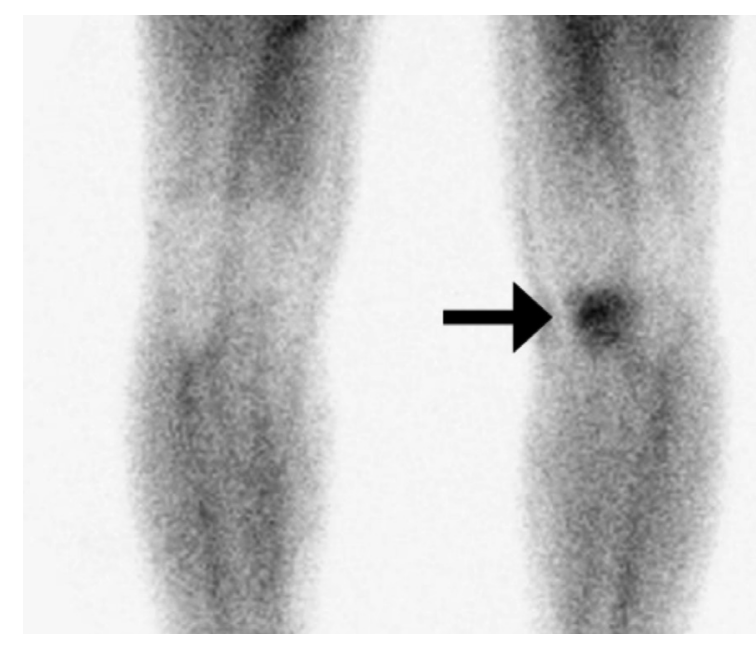

Figure 1. Blood pool phase of 3-phase bone scintigraphy (3-PBS) showing hyperemia in the left knee joint. 3-PBS, revealing the pathologic changes in osseous compartments as early as a few days after the onset of complaints, is a widely used method in the diagnosis of stress fractures.

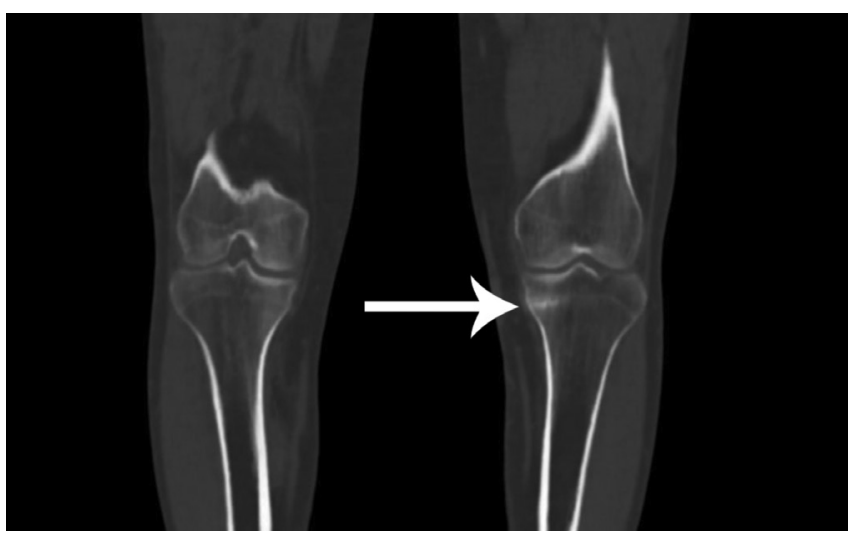

Figure 3. Computed tomography (CT) image from single-photon emission CT (SPECT)/CT fusion study showing a linear fracture in the proximal tibia. While distal and middle third of the tibia are the most frequent sites for stress fractures (almost 50\%), stress fractures of the proximal tibia is relatively rare and could be confused with other types of tibial fractures (1). SPECT/CT, which combines the high anatomical resolution of CT with the early-diagnosis capability of SPECT, is an increasingly preferred imaging technique in the diagnosis and follow-up of these patients (2).

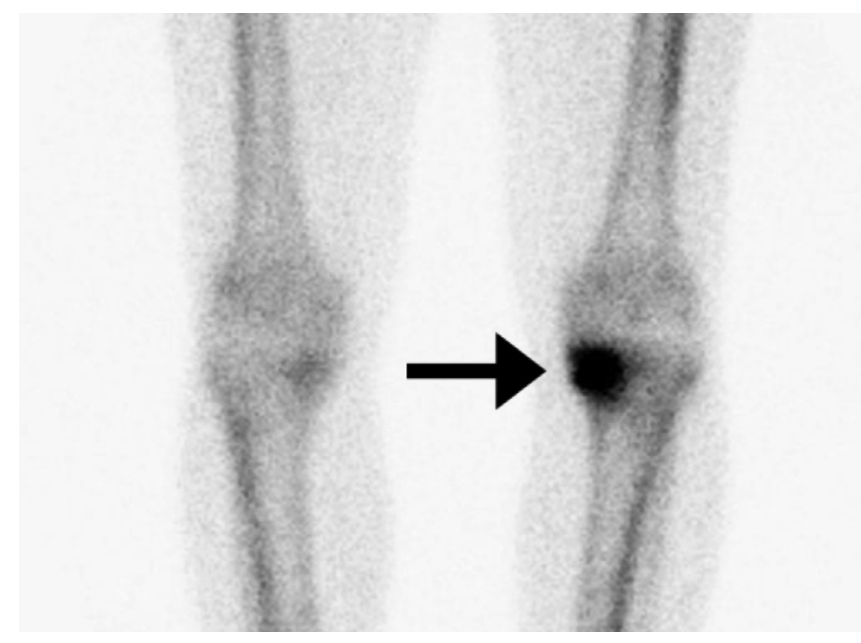

Figure 2. Delayed phase 3-PBS showing increased activity in the left knee joint.

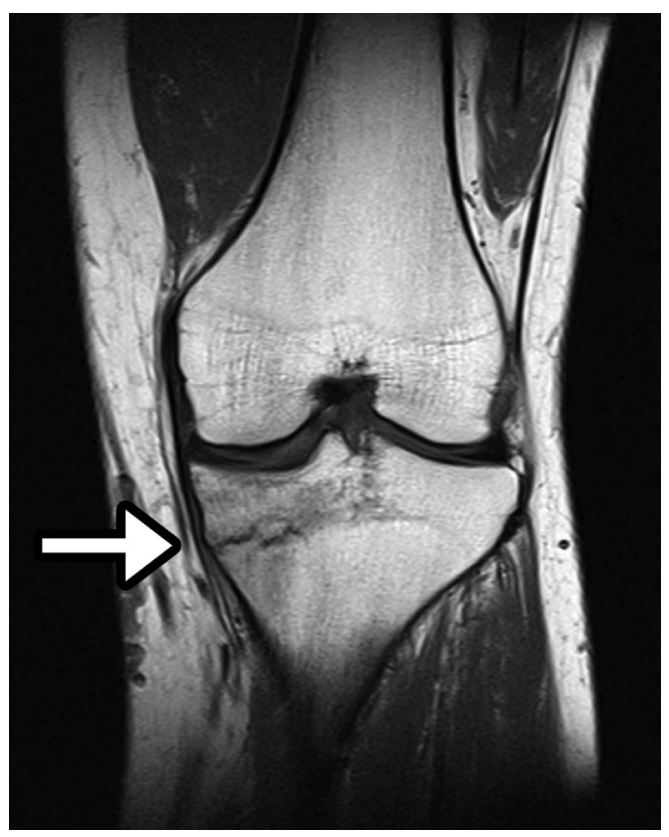

Figure 4. Magnetic resonance image confirming the stress fracture line in the proximal tibia. 


\section{Ethics}

Informed Consent: Consent form was filled out by all participants.

Peer-review: Externally peer-reviewed.

\section{Authorship Contributions}

Surgical and Medical Practices: B.O., N.C., Concept: B.O., N.C., Design: B.O., N.C., Data Collection or Processing: B.O., N.C., Analysis or Interpretation: B.O., N.C., Literature Search: P.A., Writing: N.C.
Conflict of Interest: No conflict of interest was declared by the authors.

Financial Disclosure: The authors declared that this study received no financial support.

\section{References}

1. Drabicki RR, Greer WJ, DeMeo PJ. Stress Fractures Around the Knee. Clin Sports Med 2006;25:105-115.

2. Huellner MW, Strobel K. Clinical applications of SPECT/CT in imaging the extremities. Eur J Nucl Med Mol Imaging 2014;41(Suppl 1):S5058. 